DOI:http://dx.doi.org/10.18524/1810-4215.2019.32.182231

\title{
MATHEMATICAL MODEL AND METHOD OF OPTIMAL PLACEMENT OF OPTICAL-ELECTRONIC SYSTEMS FOR TRAJECTORY MEASUREMENTS OF AIR OBJECTS AT TEST
}

\author{
A.D. Tevjashev ${ }^{1}$, I.S. Shostko ${ }^{1}$, M.V. Neofitnyi ${ }^{1}$, S.V. Kolomiyets ${ }^{1}$, \\ I.Yu. Kyrychenko ${ }^{1}$, Yu.D. Pryimachov ${ }^{2}$ \\ ${ }^{1}$ Kharkiv National University of Radio Electronics, \\ Kharkiv, Ukraine, iryna.kyrychenko2@nure.ua \\ ${ }^{2}$ V.N. Karazin Kharkiv National University, \\ Kharkiv, Ukraine
}

\begin{abstract}
To study the dynamic properties of the new generation of airplanes, helicopters, unmanned aerial vehicles, rocket and artillery weapons and ammunition at test sites (polygons) use mobile laser optical-electronic stations of the trajectory of measurement (LOETMS). Each LOETMS provides the detection of test air objects in the visible and infrared spectral ranges, their high-precision tracking, measurement and delivery of the parameters of the coordinates of the movement of air objects in real time. In order to eliminate systematic and suppress random errors of trajectory measurements, LOETMSs are integrated into a unified polygon informationmeasuring system (UPIMS). Since the cost of each LOETMS is high enough, when constructing the UPIMS, the problem arises of choosing the minimum number of LOETMSs and their location along the test tracks of the polygon so that the dispersion of estimates of the parameters of the coordinates of
\end{abstract} the movement of air objects is minimal or at least less than or equal to a given threshold. The report provides a mathematical formulation and solution of the two-criterion problem of optimal placement of LOETMS on the territory of the polygon. The main attention is paid to the mathematical formulation and the method of solving the problem of metrological certification of the UPIMS for a fixed number and location of LOETMSs along the test tracks of the polygon. It is shown that the solution of the UPIMS metrological certification problem is reduced to linearizing the non-linear function of random arguments (model of the trajectory of air objects) and calculating the dispersions of dependent variables (parameters of motion coordinates) from known dispersions of independent variables. The results of solving the problems of optimal placement of LOETMSs on the territory of the polygon and metrological certification of UPIMS are given. The studies are relevant not only for field testing of aircraft, but also of scientific and practical interest in the construction of monitoring systems for airspace in the visible and infrared spectral ranges and the study of the trajectories of objects of artificial and natural origin in the Earth's atmosphere.

АНОТАЦЯ. Для дослідження динамічних властивостей нового покоління літаків, вертольотів, безпілотних літальних апаратів, ракетного та артилерійського озброєння i боєприпасів на полігонах використовують мобільні лазерні оптико-електронні станції траєкторії вимірювання (ЛОЕСТВ). Кожна ЛОЕСТВ забезпечує виявлення випробовуваних повітряних об'єктів у видимому i інфрачервоному діапазонах спектру, їх високоточне супровід, вимір і видачу параметрів координат руху повітряних об'єктів в режимі реального часу. Для усунення систематичних і придушення випадкових помилок траєкторних вимірювань ЛОЕСТВ інтегруються в єдину інформаційновимірювальну систему полігону (ЕІВСП). Так як вартість кожної ЛОЕСТВ досить висока, то при побудові ЕІВСП виникає проблема вибору мінімальної кількості ЛОЕСТВ і їх розташування уздовж випробувальних трас полігону таким чином, щоб дисперсія оцінок параметрів координат руху повітряних об'єктів була мінімальною або, принаймні, менше або рівною заданому порогу. $\mathrm{y}$ доповіді наводиться математична постановка i рішення двухкритеріальної задачи оптимального розміщення ЛОЕСТВ на території полігону. Основна увага приділена математичній постановці і методу рішення задачі метрологічної атестації ЕІВСП для фіксованої кількості та розташування ЛОЕСТВ уздовж випробувальних трас полігону. Показано, що рішення задачі метрологічної 
атестації ЕІВСП зводиться до лінеаризації нелінійної функції випадкових аргументів (моделі траєкторії руху повітряних об'єктів) і розрахунку дисперсій залежних змінних (параметрів координат руху) від відомих дисперсій незалежних змінних. Наводяться результати вирішення завдань оптимального розміщення ЛОЕСТВ на території полігону та метрологічної атестації ЕІВСП. Проведені дослідження актуальні не тільки для полігонних випробувань літальних апаратів, а й представляють науковий і практичний інтерес, при побудові систем моніторингу повітряного простору в видимому і інфрачервоному діапазонах спектру i дослідження траєкторій руху об'єктів штучного і природного походження в атмосфері Землі.

Key words: trajectory measurements, informationmeasuring system, laser optoelectronic stations, optimal placement, mathematical model of coverage.

\section{Introduction}

Increasing the efficiency of use of modern weapons leads to the need to expand the dynamic and functional characteristics of aircraft (aircraft), cruise and antiaircraft guided missiles, models of artillery equipment. Under these conditions, the problem of the study of the dynamic characteristics of LA, testing and evaluation of their extreme (maximum permissible) characteristics becomes extremely relevant (Dodonov \& Putiatin, 2017).

The mobile laser optical-electronic stations of the trajectory of measurement (LOETMS) developed at KHNURE (Semenets et al., 2018) can be used for various flight experiments, certification of aircraft and rocket-artillery systems, providing trajectory information and video information to control the characteristics of various aircraft with coordinate measurement, observation and recording of video information and subsequent detailed analysis of the dynamic and functional characteristics of the investigated aircraft.

Each LOETMS in its area of responsibility is programmed to track a target in a predicted path segment. The programming process is automated and runs simultaneously for all LOESTI. To synchronize and adjust the delivery of goals for each LOETMS, the technology of wireless sensor information and communication network is used in the process of aircraft maintenance. Each LOETMS in the process of tracking an aircraft transmits its current coordinates via a communication channel to LOETMS, which is in the waiting queue. Based on these data, the coordinates of the expected capture point and the flight path of the aircraft are adjusted relative to the predicted.

The article presents a mathematical formulation and a method for solving the problem of optimal placement of LOETMS along the most probable flight paths of an aircraft over the territory of the the test site. Before conducting flight tests, this problem must be solved, and the relative position of LOETMS on the territory of the test site is known. To determine the coordinates of each LOETMS, we use dual-frequency GPS receivers mounted on the vertical axis of the LOETMS supporting and turning arrangement. The results of measuring the coordinates of each LOETMS and their errors are entered into the LOETMS database and are periodically updated in accordance with the regulations. Thus, UPIMS is a set of spatially distributed, interconnected wireless sensor information and communication networks LOETMS and other auxiliary technical means for receiving video and measuring information, its transformation, processing in order to present data on the trajectory parameters of the observed aircraft in the required form.

Significant spatial distribution of LOETMS on the test site, the need to take into account the errors of binding coordinates of each LOETMS to the topobase using the global navigation satellite positioning system (GPS), the errors of leveling the LOETMS platforms, alignment errors (linking each local spherical coordinate system of LOESTI to the global geocentric coordinate system), individual metrological characteristics of each LOETMS, identifying and eliminating systematic errors and suppressing random errors of general measurements by several LOETMS, led to the fact that the problem of metrological certification UPIMS aircraft is extremely complex and relevant.

\section{The structure and purpose of the complex}

Supporting and turning arrangement on which are installed:

- visible range camera;

- thermal camera with teleobjective lens;

- laser ranging equipment;

- GPS receiver for geodetic reference;

- Horison laser level for positioning supporting and turning arrangement;

Fig. 1 and Fig. 2 show views of the turning arrangement (Semenets et al., 2018).

The purpose of the system. Designed to solve a wide range of tasks of monitoring airspace in the optical and infrared ranges:

- detect all moving objects;

- automatic recognition of the type of aircraft;

- selection (automatic / manual) of a specific object; 


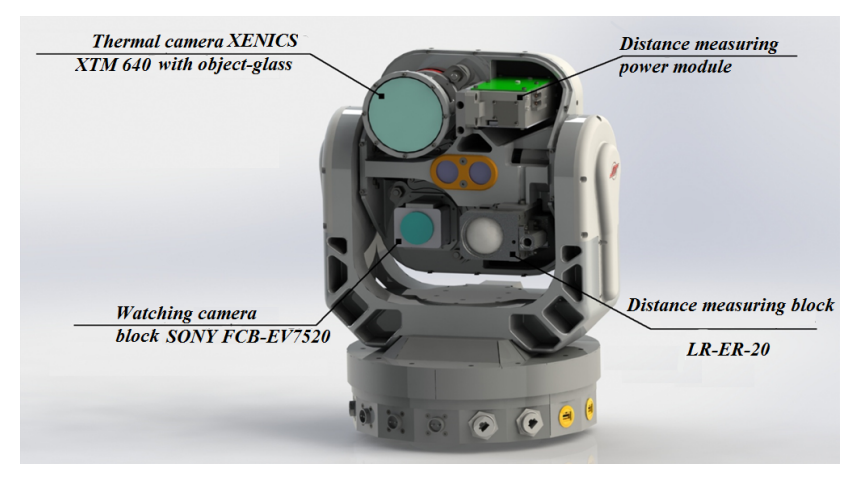

Figure 1: Front view of the turning arrangement

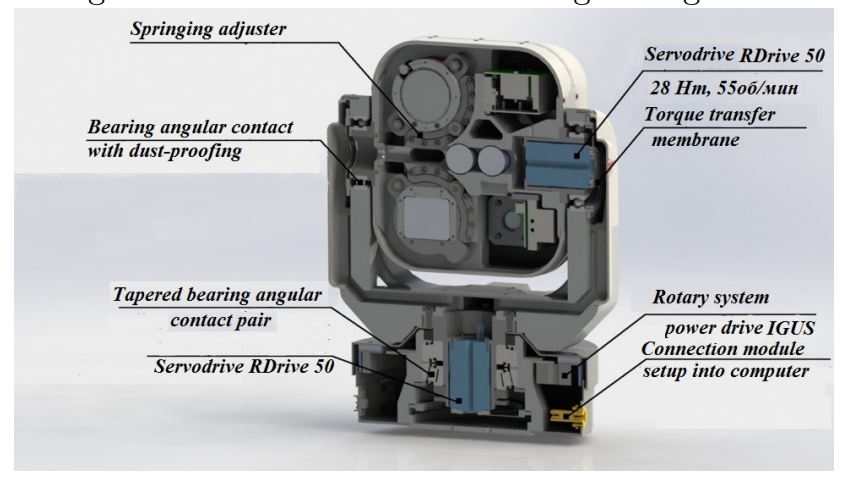

Figure 2: Back view of the turning arrangement

- its precision tracking;

- automatic calculation of coordinate parameters (coordinates, velocity projections) of each moving object in the local (spherical) and global (Greenwich) coordinate systems.

\section{Task and goals of work}

The problem can be formulated as follows: it is necessary to completely cover a certain rectangular area, called the coverage area, with some objects, called nodes of the wireless sensor network, so that the observed point of the object is detected by three nodes at the same time, while technological restrictions are observed.

One of the technological limitations may be restrictions on the minimum and maximum allowable distances between the centers of the nodes of the wireless sensor network and the border of the coverage area, as well as between the centers of the "neighboring" nodes of the wireless sensor network (Antoshkin et al., 2001).

The aim of the work is to develop a mathematical model and optimize the placement of nodes of the wireless sensor network in the rectangular region of a unified polygon information-measuring system.

The object of study is the process of mathematical modeling and optimization of the placement of nodes of a wireless sensor network in a unified polygon information-measuring system.

The subject of the study is optimization methods for covering a rectangular area with LOETMS control zones.

\section{Domain description}

There is a need to create control and management systems in which the objective function is defined not only as a direct assessment of the characteristics and conditions of the object, but also with the help of some additional (for example, signal) information. A physical model linking the characteristics of the object and additional information should be constructed in such a way that it is possible to track and diagnose the parameters of the object.

In this case, each controlled point in the region should be in the coverage area of at least one receiver (sensor). The area that the sensor controls is shown as a circle. Then, the qualities of an adequate model of control and monitoring systems can be considered the circular coverage (circles) of the region $R^{2}$ with additional restrictions arising from the physical characteristics of the equipment used (Antoshkin \& Pankratov, 2016).

\section{Solving the problem of regular coverage of a rectangular area}

In (Fejes Toth, 1972), the coverage criterion is defined as follows: for the $\Omega$ set, which should be a circular cover for the $\Upsilon$ set, it is necessary and sufficient that any intersection point of the circles belong to at least three circles, and each intersection point of the circle and the boundary of the region belong to at least two circles, as shown in Fig. 3.

As part of this task, we assume that the area of a unified polygon information-measuring system is a rectangle.

It is known (Fejes Toth, 1972) that the optimal coverage of a plane with circles is achieved using the socalled regular or lattice coverage. Therefore, we use regular coverage to cover the rectangle with circles.

The set-theoretic model of the problem of covering a rectangle $P$ with the number $n$ of circles is as follows:

$$
P \subset \bigcup_{i=1}^{n} C_{i}
$$

That is, each point of the region $T_{0}$ belongs to at least one of the circles $C_{1}, C_{2}, \ldots C_{n}$. The mathematical model of the task in the absence of additional restrictions can be represented as: 


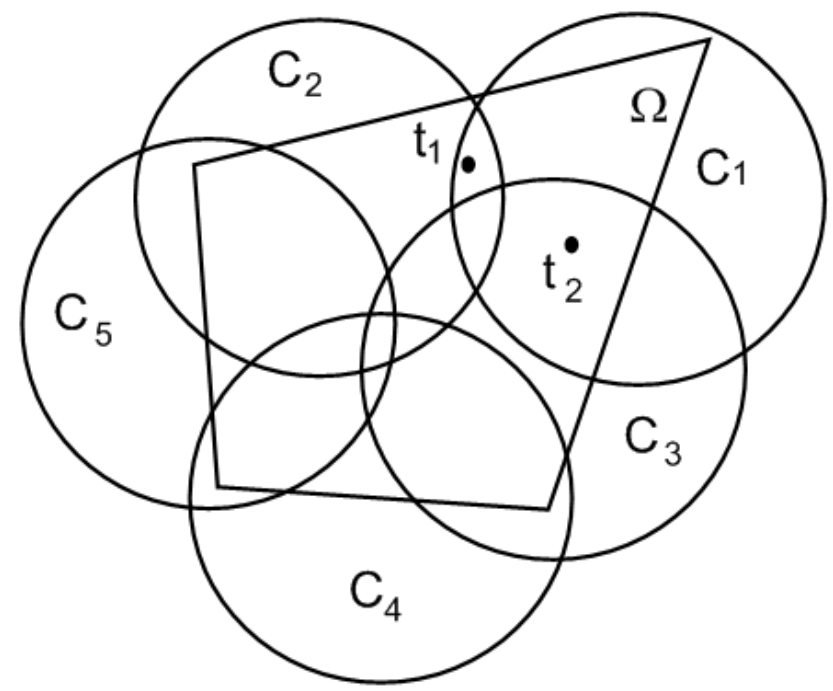

Figure 3: Coverage criteria

$$
\max _{t \in T_{0}} \min _{i \in I_{n}} \rho\left(t_{i} t\right) \leq R,
$$

where $r h o\left(t_{i} t\right)$ - distance between points; $t_{i}$ and $t t=$ $\left(t_{x}, t_{y}\right) \in \Omega ; t=\left(x_{i}, y_{i}\right)$ - center of $\mathrm{i}$-th circle; $I_{m}=$ $\{1,2, \ldots m\}, R$-radius of circles.

The set of vectors:

$$
r=n a_{1}+m a_{2}, n, m \in Z,
$$

where $a_{1}=\left(a_{1 x}, a_{1 y}\right), a_{2}=\left(a_{2 x}, a_{2 y}\right)$ - linearly independent, is called a lattice with basis $a_{1}, a_{2}$ and is denoted $L=\operatorname{Lambda}\left(a_{1}, a_{2}\right) ; Z$ - the set of integers, Lambda - the operator that maps the set of pairs of vectors to the set of families of the form (3).

Covering $\left\{\tau_{y}\right\}, i, j \in Z$ with planes in circles $\tau_{u}=$ $\tau\left(i a_{1}+j a_{2}\right)=\tau(0,0)+i a_{1}+j a_{2}, i, j \in Z$ is called a single (lattice-frequent) covering of the circle $\tau(0,0)$ which is performed along the basis $\left(a_{1}, a_{2}\right)$ of the lattice $L=\left(a_{1}, a_{2}\right)$ where $\tau(0,0)$ circle $\tau$ centered at $(0,0)$.

The solution method is to generate (with a given step) a set of basis vectors that guarantee the existence of a accomplished covering by the constructed bases, and choose the best of the constructed lattice coverings.

Now we turn to the problem of the correct sectionalregular coating of the rectangle using circles. The solution to this problem is reduced to the solution of two problems of covering a rectangle with vertically and horizontally located sections of a rectangular shape. Since the tasks in the statement coincide, in what follows we restrict ourselves to considering the first of them.

The objective function of this problem has the same properties as the objective function of the problem of regular covering of a rectangle, with the exception of periodicity. In addition, the dependence of the result on the parameters is complex and difficult to formalize. This leads to the need to use approximate methods for solving the problem. For example, the application of the method of applying a grid to the region of possible solutions allows us to solve the problem of sectionalregular coating in two stages (Pankratov et al., 2002):

- solving a number of problems of uniform regular cutting of sections $A \times h_{k}$ by the method described above;

- item selects the optimal combination of sections.

First, it is worth solving a number of inverse problems of regular coverage. Namely, for a given number of detection zones, it is necessary to determine the maximum possible section size, it is covered by a given number of detection zones. It should be noted that when solving the problem of regularly covering the entire rectangle with this method, all these solutions can be obtained as intermediate results.

We now turn to solving the problem of choosing the optimal set of sections. In its statement, this problem is similar to the well-known one-dimensional knapsack problem (Korbut \& Filkenshtein, 1969) if we interpret the number of circles $k$ located in the section as the weight of the element, and the value $h_{k}$ as the length of the element. However, the function of the goal in this case is unconventional, namely: it is necessary to find a set of elements of minimum weight, providing overflows or at least full filling of the knapsack.

An interesting feature of the proposed method for constructing section-regular coatings is that it can be naturally generalized to the case of dividing a rectangular region into sections that are regularly covered with circles of different radii.

In Fig. 4 and 5 show the results of separation of sections of regular and regular coverage of section A using circles of radius 5700, respectively. Although both coatings are formed by 31 circles, regular sectional coating is preferable as it is more technologically advanced.

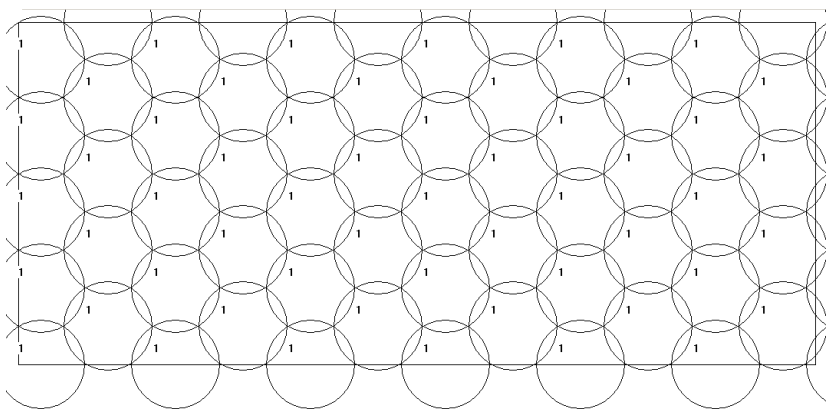

Figure 4: Regular coverage 


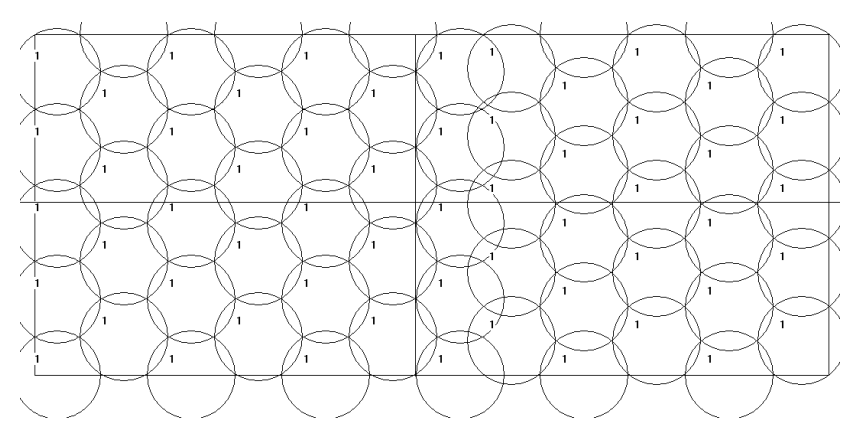

Figure 5: Sectional-regular coverage

In accordance with theoretical considerations, as the number of circles increases, a method of sectionalregular coverage gives less and less advantage than a method of regular coverage. For the entire plane, the use of sectional-regular coverage will lose its meaning. However, for the vast majority of practical tasks, the use of sectional-regular coverage gives a significant effect.The coverage criterion is considered equal to the total area of the covering circles.

\section{Conclusions}

Since the study solves the problem of the optimal placement of LOETMS along the most probable flight paths of an aircraft over the training ground, an important class of problems is created for creating circular coatings covering a rectangular area.

A mathematical model and optimization of the location of the nodes of the wireless sensor network in the rectangular region of a unified polygon informationmeasuring system is proposed.

Using methods of regular and sectional-regular coverage, the stated problem of the need for a certain rectangular area, called the coverage area, can be completely covered by some objects, which are called nodes of the wireless sensor network, so that the observed point of the object is detected simultaneously by three nodes, each time subject to technological limitations.
Coverage criteria highlighted: in order for one multitude to be a circular cover of another multitude, it is necessary and sufficient that any intersection point of the circles belong to at least three circles, and each intersection point of the circle and the boundary of the region belong to at least two circles.

Thus, using these methods and meeting the criteria, the task is completed - the observed point of the object is detected simultaneously by three points.

For the vast majority of practical applications, the method of sectional-regular coatings has an advantage over the method of regular coatings.

\section{References}

Antoshkyn A.A., Pankratov A.V., Patsuk V.N., Romanova T.E., Shekhovtsov S.B.: 2001, Radioelektronika $i$ informatika, Khar'kov: KHNURE, N 3, 31 (in Russian).

Antoshkin O., Pankratov O.: 2016, EasternEuropean Journal of Enterprise Technologies, 6, N 4(84), 45. DOI: 10.15587/1729-4061.2016.86171.

Dodonov A.G., Putiatin V.G.: 2017, Matematychni mashiny i systemy, 4, 30 (in Ukrainian).

Fejes Toth L.: 1972, Acta Math. Acad. Sci. Hungar, 24, 417 .

Korbut A.A., Finkel'shteyn Yu.Yu. Diskretnoye programmirovaniye. M.: Nauka, 1969. 368 s. (in Russian).

Pankratov A.V., Patsuk V.N., Romanova T.Ye., Antoshkin A.A.: 2002, Radioelektronika $i$ informatika, 1(18), 50 .

Semenets' V.V., Tevyashev A.D., Shostko I.S., Neofitnyy M.V., Kolyadin A.V.: 2018, Tezy dopovidey VI Mizhnarodnoyi naukovo-praktychnoyi konferentsiyi "Problemy koordynatsiyi voyennotekhnichnoyi ta oboronno-promyslovoyi polityky $v$ Ukrayini. Perspektyvy rozvytku ozbroyennya ta viys 'kovoyi tekhniky" (Kyiv, 11-12 zhovtnya 2018), p. 234 (in Ukrainian). 